\title{
States' Rights and States' Roles: \\ Permutations of "Sovereignty" in \\ National League of Cities v. Usery*
}

\author{
Frank I. Michelman ${ }^{\dagger}$
}

A share of the blame for what follows belongs to Mr. Justice Brennan, whose twenty years of distinguished labor on behalf of our constitutional system-on behalf, I should say, of the men, women, and children whose rights and concerns that system serves-this journal justly celebrates.

It was the Justice who, by his striking and powerful dissent in National League of Cities $v$. Usery (NLC), ${ }^{1}$ first made me think there must be even more to that case than meets the eye. His opinion is remarkable for its depth of feeling, its sense of occasion, of foreboding, of fatal and momentous choice. The eloquence is disciplined and surgical-not so sweepingly flamboyant as, say, the impassioned Frankfurter's, ${ }^{2}$ but as stirring. The opinion speaks with a controlled intensity that at first seems disconsonant with both the immediate impact of the Court's decision (denial of congressional minimum-wage protection to state and municipal employees) and its broader doctrinal significance (recognition of some state governmental immunity from congressional regulation under the commerce clause). Both developments, to be sure, are important. But it seems unlikely that the immediate impact taken by itself-if, say, it had resulted from a disputable statutory

- This article has a kinship with Professor Laurence Tribe's article, Tribe, Unraveling National League of Citics: The New Federalism and Affirmative Rights to Essential Government Services, 90 Harv. L. REv. 1065 (1977). Our two efforts are to a considerable extent overlapping in content and perception, yet also marked by significant differences in aim, approach, and argumentation. They took shape in our respective minds simultaneously, during the fall of 1976, at Harvard Law School, where we exchanged idcas both directly and through our students. Neither of us is surprised at the family likeness in the finished pieces. Consolidating our efforts into a single, co-authored essay was a possibility that, for various reasons, finally seemed less attractive than letting both be published, each carrying this footnote which is meant to serve as a reciprocal release from the duty-performance of which would fast become tedious-of point-by-point crosscitation.

+ Professor of Law, Harvard University.

1. 426 U.S. $833,856-80(1976)$.

2. Sec, e.g., Baker v. Carr, 369 U.S. 186, 266-330 (1962) (Frankfurter, J., dissenting). 
interpretation rather than from a broad affirmation of constitutionally based states' rights-can explain Justice Brennan's dramatic response. ${ }^{3}$ Similarly, the states' rights development, as surprising as it seems to many in light of the most immediately relevant precedents, had long been a possibility latent and unresolved in tax-immunity doctrine, ${ }^{\overline{5}}$ and recently had been foreshadowed by Court decisions reflecting special sensitivity to a state's interest in retaining control over its internal governmental arrangements. ${ }^{6}$ Why, then, this most arresting protest now?

We can begin with Justice Brennan's attack on the Court's statesovereignty notion as "an abstraction without substance." 7 As will appear, ${ }^{8}$ I think the Justice risked some misunderstanding-perhaps even missed an important point-when he put the matter just that way. But there is enough truth in his charge to let it serve as the starting point for analysis of the sovereignty notion set forth in $N L C$. For, as we are about to find, it is no easy matter to ascribe operational content to that notion-to specify the distinctively "sovereign" attributes that render states resistant to commerce-clause regulation-so that the notion will be both internally intelligible and consistent with the totality of the NLC decision and its reasoning. One might intuitively think that a state's sovereignty must consist in some or all of the special powers it has as a legislative authority; or in the crucial choices it makes (through exercise of those powers) about the basic allocation and definition (or "structure") of roles and functions in society; or in the special ("political") processes of choice that characterize it. But each of those interpretations is ruled out by some or another aspect of the $N L C$ decision itself. The only interpretation that is compatible with the decision taken as a whole, I shall argue, is a surprising one that leads in directions the Justices do not seem to have intended or anticipated.

3. Compare NLRB v. Natural Gas Util. Dist., 402 U.S. 600 (1971) (Brennan, J.) (holding respondent District an exempt "political subdivision" under National Labor Relations Act $\$ 2(2), 29$ U.S.C. $\$ 152(2)(1970)$ ).

4. Fry v. United States, 421 U.S. 542 (1975); Maryland v. Wirtz, 392 U.S. 183 (1968);

Case v. Bowles, 327 U.S. 92 (1946); United States v. California, 297 U.S. 175 (1936).

5. See, e.g., New York v. United States, 326 U.S. 572 (1946). Justice Brennan's dissent in $N L C$ is least persuasive in disputing with the majority over the significance of the tax-immunity decisions. 426 U.S. at 869-70 \& n.10.

6. See Milliken v. Bradley, 418 U.S. 717 (1974); Mayor of Philadelphia v. Educational Equality League, 415 U.S. 605 (1974); San Antonio Independent School Dist. v. Rodriguez, 411 U.S. 1 (1973); cf. James v. Valtierra, 402 U.S. 137 (1971) (state's interest in maintaining democratic decisionmaking processes).

7. 426 U.S. at 860 .

8. See pp. $1192-94$ infra. 
I. 'Transcendental Nonsense: The Real Meaning of States' Rights and "Sovereignty" in NLC

The problem of infusing the abstraction of state sovereignty with legal substance is that of picking out those instances of congressional action that are constitutionally questionable because they impinge directly on "states." Despite the Idealist overtones in NLC's references to "States as States,"' the Court plainly means "state" in the historically contingent sense of state-in-the-federal-system; not State as a philosophical absolute like Family, Corporation, or Individual. Still, we need some way of differentiating "the states" from "the people."10 Just about everything Congress does is intended to affect persons who in fact are citizens of states, and whose activities or property in fact are found within the borders of states; and every one of these effects is, as likely as not, discrepant in some way from what the citizenry of one or another state would have chosen for itself. Presumably only a select few of these effects will ever be regarded as impinging on "states as states."

It might seem that there is no great mystery about how to distinguish "the states" from "the people." We know perfectly well, granting that there are intermediate hard cases, 11 how to distinguish governmental from nongovernmental powers and forms of organization: governments are distinguished by their acknowledged, lawful authority-not dependent on property ownership-to coerce a territorially defined and imperfectly voluntary membership by acts of regulation, taxation, and condemnation, the exercise of which authority is determined by majoritarian and representative procedures. ${ }^{12}$ It may well be this common-sense distinction that the Court has in mind. But why so? What is it about organizations having these governmental attributes that makes them (as distinguished from all the other agencies that operate within a state under the sanction of its laws and institutions) specially needful of protection from congressional interference?

Prompted by the Court's Idealist locutions we might wonder whether the Justices had in mind something akin to a Hegelian distinction between "state" and "civil society"-where "civil society" stands for

9. E.g., 426 U.S. at 845 (emphasis added).

10. That is, the Court's decision requires such a differentiation although, as Justice Brennan reminds us, the Tenth Amendment does not. See 426 U.S. at 868 n.9.

11. See, e.g., NLRB v. Natural Gas Util. Dist., 402 U.S. 600 (1971).

12. In the final analysis, it may be only organizational forms, not powers, that allow for a common-sense distinction between governmental and nongovernmental agents. See, e.g., F. Michelmix \& T. S.INd.hlow, Governisit in Urian Akeds 119-27 (1970); Cohen, Properly and Sovereignly, 13 CoRxell L.Q. 8 (1927); Jaffe, Law Making By Privale Groups, 51 H.akv. L. REv. 201 (1937). 
institutionalized accommodation of the interplay of particular wills and interests, and "state" represents the transcendence of those particular wills and interests in universal principles of right. But we need not wonder long. For if the essence of statehood were considered to be the generation of universal principles of right (subject, of course, to the authority of Congress within its limited sphere of competence), then the combined results of the preemption doctrine, ${ }^{13} \mathrm{NLC}$, and United States $v$. Darby ${ }^{14}$ (in which the Court upheld against a claim of states' rights the power of Congress to regulate wages in the private sector) would be just precisely wrong: congressional action in areas of disputable federal competence would be most vulnerable insofar as it displaced the state from its role of universal legislator and law-enforcer, and least vulnerable insofar as it curbed the state in its guise of active agent having particular interests opposed to other particular interests such as those of its employees. ${ }^{15}$

What is it, then, that is especially significant about governmental powers and forms, if not some link between them and the role of the state as a maker and enforcer of laws? Possibly the significance of governmental powers and forms is thought by the Court to lie in their connection with certain (kinds of) welfare-related social functions. The government, then, far from being opposed to civil society, would be seen as a part of it: the people self-organized to perform functions conducive to their welfare.

But if we adopt such a welfare-oriented, functional view of the government as service-provider, we are again at a loss to explain why a state's immunity to congressional regulation should encompass only its governmental organs. For on such a view the state must be something that stands behind, that shapes and structures a civil society in which the government is but one among many agents. That statestructured civil society consists of a set of rules and practices that allocate powers, some plainly "public" or "governmental," some

13. E.g., Burbank v. Lockheed Air Terminal, 411 U.S. 624 (1973).

14. 312 U.S. 100 (1941). "[I] th said that ..., under the guise of a regulation of interstate commerce, [the challenged statute] undertakes to regulate wages and hours within the state contrary to the policy of the state which has elected to leave them unregulated." Id. at 114. The Darby decision was reaffirmed in NLC. 426 U.S. at 836.

15. Compare National League of Cities v. Usery, 426 U.S. 833, 875 (1976) (Brennan, J., dissenting). It does not help to describe $N L C$ as protecting the state's role of legislating the terms on which its agencies and prospective employees may contract with one another, because that would not explain why the state does not enjoy the same protection for its role of legislating employment terms for the private sector. Plainly, the distinction between $N L C$ and Darby can only be that in $N L C$ the state is, whereas in Darby it is not, affected in its capacity as an agent pursuing particular interests. 
plainly "private" or "proprietary," some hard to classify. ${ }^{16}$ A state's "choice" to allocate (including its inclination to leave) powers and functions to private organs seems no less significant or purposive than its choice to create governmental responsibilities; its choice to create spheres of decentralization, or of unregulated market activity, seems no less significant or purposive than its choice to create spheres of centralization or collectivization. ${ }^{17}$ Neither type of choice seems any more a matter of a state's "internal affairs," or "integrity," or "structure," than the other. Indeed, neither type is intelligible except with regard to the possibility of the other, and there seems no a priori ground for treating either of the reciprocally defining possibilities as primary. "Structure" seems to be just the totality of the choices. If so, Darby countenances a congressional impingement on the structural affairs of states no less momentous than the one averted in NLC.

We have seen, then, that a state's "sovereignty," as conceived in $N L C$, can consist neither in a notion of the state as the object of political loyalty and legitimate arbiter of rights, nor in a notion of the state as the embodiment of political choice about the basic "structuring" of roles and functions in civil society. That neither of those was in fact the Court's notion is strongly confirmed by its decision to include municipal governments under the state's protective "sovereignty" mantle. That this decision was a focused and deliberate one is clear on the face of the opinion. ${ }^{18}$ That it was by no means an inevitable one is clear from the established doctrine denying municipalities immunity from suit in federal tribunals, which "states" enjoy under the Eleventh Amendment. ${ }^{19}$ The NLC opinion offers no

16. See F. Michelman \& T. S.sdizow, supra note 12, at 119-27. Among the most engaging and revealing examples arc the municipalitics immunized from congressional wage-regulation by the $N L C$ decision. Though it is no longer respectable to urge that municipalities have an "inherent right of self-government," see $i d$. at $179-80$, their "dual naturc," see, e.g., Cojle v. Gray, 12 Del. (7 Houst.) 44, 30 A. 728 (1884), is still an operative factor in our law, most characteristically when municipalities seek judicial protection for their property holdings against state legislatures. See F. Michelmax \&: T. SANDalow, supra note 12 , at $181-85$.

17. This view of the private or decentralized agent as virtually a social functionary is not mercly a major theme in much contemporary writing at the intersection of economics and law, see, e.g., R. POSNer, Economic AN.u.ysis of LAw 16-21 \& 17 n.1 (1972); Michelman, Book Review, 80 Y.ILE L.J. 647, 652-53 (1971), it reflects the pluralism, utilitarianism, and pragmatism that deeply characterize our traditional political and legal understandings. See, e.g., R. El.y, Property and Contract in Their Relations to the Distribution of Weilth (1914); O. Holmes, The Common Law 84.85 (M. Howe ed. 1963) (discussing Brown v. Kendall, 60 Mass. (6 Cush.) 292 (1850)); Note, Judicial Control of Actions of Private Associations, 76 HARv. L. REv. 983, 986-89 (1963) (collecting and summarizing "pluralist" writings). See also, e.g., Cohen, supra note 12; Jaffe, supra note 12.

18. See 426 U.S. at $855-56$ \& $n .20$.

19. E.g., Mount Healthy City School Dist. v. Doyle, 97 S. Ct. 568, 572-73 (1977). 
reason for protecting municipalities, along with states, from congressional regulation under the commerce clause, beyond noting that municipalities "derive their authority and power from their respective States." 20 But that, we have already noted, is no less true of private corporations (or of individuals in their capacities as property owners) fully exposed to congressional regulatory authority. Whatever else might distinguish municipalities from those private entities, it plainly cannot be any attribution to municipalities of a law-giving, rightsdeclaring, or "structuring" role resembling that of the state itself. ${ }^{21} \mathrm{~A}$ crucial passage in the Court's opinion strongly implies that the special solicitude for municipalities arises out of quite different concerns. The Court says that extension of the minimum wage to local governments will

significantly alter or displace the States' abilities to structure employer-employee relationships in such areas as fire prevention, police protection, sanitation, public health, and parks and recreation. These activities are typical of those performed by state and local governments in discharging their dual functions of administering the public law and furnishing public services. Indeed, it is functions such as these which governments are created to

20. 426 U.S. at 855 n.20. The need for explanation is pressing, and aggravated by the Court's apparent disregard for even the appearance of consistency in its use of labels as arguments in the regulatory-immunity and Eleventh Amendment contexts. In NLC, municipalities are labeled "subordinate arms of a state government" for purposes of allowing them to share in the state's special immunity against congressional regulation, id., but in Mount Healthy City School Dist. v. Doyle, 97 S. Ct. 568, 572 (1977), they are denied Eleventh Amendment immunity for the express reason that they are not "arm[s] of the State." And the conventional labeling of municipalities as "political subdivisions," while adhered to in both contexts, cuts in favor of municipal immunity in one case, 426 U.S. at $855-56$ n.20, and against it in the other, 97 S.Ct. at 572.

21. The common array of municipal regulatory powers is not inconsistent with the statement in the text. The powers municipalities possess have traditionally been delegated to them by enabling acts of the state legisiature. Indeed it has sometimes seemed necessary to analogize municipalities to administrative agencies in order to avoid claims of improper delegation by the legislature of its constitutional authority, leading to insistence that enabling legislation not go beyond authorization to municipalities to "make regulations or by-laws pertaining to a limited class of matters of purely local interest." E.g., Opinion of the Justices to the House of Representatives, 328 Mass. 674, 676, 105 N.E.2d 565, 566 (1952). See generally Payne, Delegation Doctrine in the Reform of Local Government Law: The Case of Exclusionary Zoning, 29 RuTGERs L. REv. 803, 82158 (1976).

Even where "home rule" provisions in constitutions either authorize far broadcr grants of authority by the legislature or make such grants directly, there is a widespread tendency to regard what has been granted as authority to provide (as it werc) a welfare-improving regulatory service, not a general authority to define rights or alter the basic legal structure of civil society-an understanding frequently expressed by insistence, either expressly in the constitution or through judicial interpretation of the constitution, that municipalities may not make "private" or "civil" law. E.g., MAss. Const. amend. 2, \$ 7; F. Michllman \& T. SA.NDiLow, supra note 12, at 314-15. But see Birkenfeld r. City of Berkelcy, 7 Cal. 3d 129, 550 P.2d 1001, 130 Cal. Rptr. 465 (1976). 
provide, services such as these which the States have traditionally afforded their citizens. If Congress may withdraw from the States the authority to make those fundamental employment decisions upon which their systems for performance of these functions must rest, we think there would be little left of the States' “'separate and independent existence." "22

So it seems that what is "sovereign" about municipalities is not their legislative position or significance, but the states' customary reliance on them to provide for the interest of citizens in receiving certain important social services. ${ }^{23}$

But perhaps this conclusion is too hasty. Perhaps sovereignty inheres in the special value or sanctity ascribed to processes of political choice as such (or of modes of community interaction that such processes are believed to foster or contain), so that special justification is required for congressional action that would directly contradict the results of such processes, or restrict the occasions for resorting to them, or curtail their effective scope. We have already noted, however, that congressional power can quite drastically impair the state's own political competence when directed to a state's private sector. ${ }^{2 \pm}$ And besides, congressional action is itself a constitutionally sanctified political process, and the general idea of a dual federalism seems to offer no firm ground for preferring the "integrity" of state and local politics to that of national politics.

Or does it? Can we perhaps read the Great Compromise as protecting the vitality of political processes at both levels by the somewhat arbitrary device of granting to Congress broad authority over the states' private sectors while sharply limiting its authority over state and local public sectors-thereby ensuring that a state can always preserve breathing space for its political life by absorbing activities into its political sphere, its governmental sector? On this view, the special harm threatened by the Fair Labor Standards Act (FLSA) amendments would be just the constricting pressure they exert on the fiscally feasible size and range of a state's (and its municipalities') governmental undertakings, with possible resultant impoverishment of political interaction at the state and local levels.

Even this last-ditch effort to connect the NLC decision with a

22. 426 U.S. at 851 (footnote omitted) (quoting Coyle v. Oklahoma, 221 U.S. 559, $580(1911))$.

23. There are repeated indications in the $N L C$ opinion of the Court's reliance on the "essentiality" or "importance" of services provided. See 426 U.S. at $845,846,847,850$, 851.

24. Pp. 1168.69 supra. 
strictly political notion of "sovereignty" is defeated by the decision itself-specifically by its refusal to extend the protective mantle of sovereignty to "areas that the States have not regarded as integral parts of their governmental activities," such as operating a railroad. ${ }^{25}$ While the Court's opinion uses the word "integral" in at least five places"s to differentiate protected from unprotected state activities or "functions," at no point does it undertake to give content to this vague locution. From the opinion as a whole one can fairly gather that "integral" has roughly the same meaning as "typical"'or or "traditional."2s But that reading means that a state's "sovereignty"-its special virtue that evokes the protection of the NLC doctrine-cannot be its embodiment of processes of political choice valued as such. For under such a sanctity-of-politics view of state sovereignty, a state's (or locality's) political choice to extend the range of its public involvements into some nontypical or nontraditional area would apparently be a quintessential instance of that very political vitality that the Constitution supposedly meant to nurture and protect.

I think we are finally forced to the conclusion that in holding that the FLSA amendments (especially as applied to municipalities) impinged upon state sovereignty, the Court in $N L C$ was using "sovereignty" to stand-rather unexpectedly-for nothing more nor less than the state's role of providing for the interests of its citizens in receiving important social services. It is only this unusual and extremely specialized sense of "sovereignty" that allows the Court to say, with

25. 426 U.S. at 854 n.18.

26. Id. at $851,852,854$ n.18, 855 (twice).

27. Id. at 851 .

28. E.g., id. at 851. At least twice the Court uses "integral" and "traditional" in intimate embrace: $i d$. at 852 ("integral operations in areas of traditional governmental functions"); id. at 855 ("an integral portion of those governmental services which the States and their political subdivisions have traditionally afforded their citizens").

No other defensible meaning for "integral," as applied to "governmental functions," comes readily to mind. A natural meaning would be functions that cannot be foregone or impaired without impairing other functions, but the Court expressly includes sereral functions-school, hospitals, parks, sanitation-which by no stretch are "integral" in that sense. Another possibility is that "integral" functions are those which exemplify some general, structured notion of a core of governmental competency or responsibility. But it is utterly unclear whether such a core can be identified at all; or what its defining principles are; or how, in any event, such an activity as railroading would be excluded from it. Is a public water-supply system in the core? A municipal bus, trolley, or rapidtransit system? What are the principles that would admit parks and sanitation systems into the core but exclude water-supply and transit systems? What principles would admit the latter but exclude an intercity or interstate railroad? I believe there are none. All that can be said about the railroad is that it is a specifically rare or novel manifestation of an established general realm of possible governmental activity-i.e., that it is atypical and untraditional-or, perhaps, that it is not as "important," or "essential," or "required" as various included activities; see p. 1171 \& note 23 supra. 
even a semblance of plausibility, that states are acting peculiarly "in their capacities as sovereign governments" when they empower municipal governments to contract with their own employees or that Congress by extending the minimum wage law to state and, especially, local governments "has sought to wield its power in a fashion that would impair the States' 'ability to function effectively . . . [within]' the federal system of government embodied in the Constitution." 29

Accordingly, we shall in the next section try to see whether such a functional view of the constitutional notion of a state-one that regards the state's service role as crucial to its special constitutional placemight be elaborated in a way that would make the $N L C$ decision respectable if not incontrovertibly right. The effort will encounter difficulties and objections that mirror, at a less abstract level, those I have raised thus far in trying to fathom the Court's more formalistic treatment.

\section{States' Roles: A Functional Approach}

A sympathetic effort to explain the result in $N L C$ might begin with the premise that deeply entrenched in the traditional and actual political practice of American federalism is an understanding that the task of providing certain important social services-such as police and fire protection, public health and sanitation, parks and recreation, education-is one that belongs chiefly to state and local governments and not to the central government. Given expansive judicial readings of the commerce ${ }^{30}$ and spending ${ }^{31}$ powers, and of the necessaryand-proper clause ${ }^{32}$ and the enforcement clauses of the Civil War amendments, ${ }^{33}$ one cannot say that this understanding is crystallized in a sharply defined constitutional doctrine. But it might be argued, with at least surface plausibility, that the Constitution's exclusive enumeration of central government powers (its restrictive implication made explicit by the Tenth Amendment ${ }^{34}$ is commonly understood to resonate the understanding; that Congress and the federal Executive

29. 420 U.S. at 852 .

30. E.g., Katzenbach v. McClung, 379 U.S. 294, 301-05 (1964); Wickard v. Filburn, 317 U.S. $111,118-29$ (1942).

31. E.g., United States v. Gerlach Live Stock Co., 339 U.S. 725 (1950); Steward Mach.

Co. v. Davis, 301 U.S. 548 (1937); Ashwander v. TVA, 297 U.S. 288 (1936).

32. McCulloch v. Maryland, 17 U.S. (4 Wheat.) 316 (1819).

33. E.g., Jones v. Alfred H. Mayer Co., 399 U.S. 409, 437-44 (1968); Katzenbach v. Morgan, 384 U.S. 641, 648-51 (1966); South Carolina v. Katzenbach, 383 U.S. 301 (1966).

34. "The powers not delegated to the United States by the Constitution, nor prohibitcd by it to the States, are reserved to the States respectively, or to the people." U.S. CoNsr. amend. $\mathrm{X}$. 
do not normally think themselves primarily or ultimately responsible for ensuring provision of the services; and that the electorate does not normally hold them accountable for failures to provide the services at acceptable levels of quality and cost. Perhaps, then, the argument would run, there is serious danger of political irresponsibility if Congress is allowed to increase the costs to state and local governments of providing the expected services, with attendant risk that their maintenance at previous levels will be made impracticable. ${ }^{35}$ The impracticability would be traceable to Congress; but the political blame would fall not on Congress but on innocent and helpless state and local governments. Such diminished coordination would impair the ability of political processes to translate popular demand for essential services into their actual provision.

This institutional argument, if otherwise sound, would have at least one clear advantage over the more formalistic states' rights claim that is apparently advanced by the Supreme Court's $N L C$ opinion. The institutional argument's use of the Tenth Amendment, if more modest than that suggested by the states' rights argument, also seems more consonant with the Amendment's text. The institutional approach can draw some support from that text insofar as we allow that the division between those "powers" that are constitutionally "delegated" and those residually "reserved" might be inferred from historical practice as well as from verbal exegesis. The Amendment can thus serve in the argument not as a source of legally deducible states' rights, but as a warning or reminder that affairs for which Congress is not held accountable-either in legal contemplation or in political practice-are also affairs in which Congress should generally not interfere. The Amendment's contribution to the argument is thus merely suggestive, and in that sense weak; but it does not entail the textual contortion required to make the Amendment operate "strongly" as a source of legally protected states' rights. ${ }^{36}$

As I have already tried to show, it is not impossible-though it does take a special, constructive effort-to see at work in the Supreme Court's own $N L C$ opinion a premise ascribing special service responsibilities to states. ${ }^{3 i}$ The plausibility of such a reading seems to be bolstered by the difficulty of otherwise explaining both Darby's co-

35. That the Court was affected by doubts about the degree of care taken by Congress to appraise the impacts of its regulations on governmental service providers is strongly suggested by the NLC opinion's description of those impacts on specialized employment practices having unique relevance to local-governmental activities. See 426 U.S. at $849-52$.

36. See id. at 868 n.9 (Brennan, J., dissenting); Shapiro, Mr. Justice Rehmquist: A Preliminary I'iew, 90 HARv. L. Rev. 293, 306-07 (1976).

37. Pp. 1167-73 supra. 
existence with $N L C$, and $N L C$ 's simultaneous extension of protection to municipalities and restriction of protection to a select class of "traditional," "integral," or "essential" governmental activities. ${ }^{38}$ Yet the "services" approach involves three counterpart puzzles.

First, Americans customarily look not only to state and local governments but also to the private sector for services in various fields that typify local government activity. There are private elementary and secondary schools, private refuse scavengers and water companies, private plant watchmen and detectives, private health insurers and hospitals, Walt Disney Enterprises and the Audubon Society. Our needs in such fields are to be served, we customarily think, by some mix of governmental and private activity. How, then, can the Court deem it any less perniciously irresponsible for Congress to impose a minimum-wage burden on the private than on the governmental share of the total supply on which we depend?

Second, why should a select group of social services have protection that other goods and services (e.g. automobiles, haircuts) do not? The Court's answer seems to be that some services have an "essential" (or "important," or "required") quality that makes clumsy congressional interference peculiarly pernicious with respect to them. But there is a deep puzzle in characterizing as peculiarly "essential" services that-by the Court's hypothesis-local voter majorities might refuse to buy at tax prices that reflected minimum-wage costs. No one denies-and while Darby stands no one could deny-that it is within the province of Congress to determine that a virtually universal minimum wage will promote the economic interests of the whole nation. While Darby and the amended FLSA both stand, one has to accept that Congress has, authoritatively and unchallengeably, determined both that the universal minimum wage will have some beneficial national economic consequence and that the congressional judgment, whatever it is, is a good or appropriate one. It follows that the costs of paying the minimum wage are a part of the (authoritatively determined) social costs of any productive process using hired labor. Goods or services that cannot be provided and sold to a willing electorate at a tax price that covers those costs are, then, apparently less "essential" than whatever it is the people prefer to purchase instead. It hardly seems apt to call "essential" a group of governmental services that the electorate will buy only insofar as those services receive a (relative) subsidy in the form of exemption from an otherwise universal minimum wage. Or at least that is not an apt way of talking under the

38. Pp. 1171-73 supra. 
standard democratic assumptions of voter and consumer sovereignty. The third puzzle is intertwined with the second. For the Court to rely on the supposed "essentiality" of local government services entails a judicial rejection not only of local consumer and voter sovereignty but also of congressional cost-benefit appraisals-a judicial determination that the marginal local-government services (those that would be priced out of the local political "market" by the cost of complying with the amended FLSA) are more "essential" or valuable than the ameliorative goals, whatever they are, that Congress is pursuing through the FLSA amendments. These substitutions of judicial for political and market solutions to social-welfare tradeoffs pose an embarrassing question of judicial method. The Court's official position has been that valuation of conflicting welfare concerns is not a proper judicial function. The conceded "social importance" of an interest or need provides, according to the established view, no basis for a court's demanding special governmental solicitude for that interest or need. ${ }^{30}$ Only constitutional recognition of an interest as a "right" can provide such a basis, but none of the social services that ostensibly stirred the Court's concern in the $N L C$ case can claim such recognition. ${ }^{40}$ The three puzzles can now be summarized:

1. If we can pick out certain social services as "essential," why should protection from irresponsible congressional interference with the process of producing these services be extended only to governmental, and not also to private, suppliers?

2. How can any select group of services be termed "essential"meaning that there is special need to prevent their being priced by a wage minimum beyond the limits of local electoral tolerancewithout contradicting the tenets of local consumer and voter sovereignty, and of supreme congressional competence to define national economic interests and choose the means of realizing them?

3. Even if it is possible for someone to make a nonpolitical designation of "essential" services while avoiding the contradictions posed in Puzzle 2, how may the Court do that without violating positivistic limits on its proper role, which the Court has seemed to embrace?

Let us consider a possible answer to the third puzzle-one which, if it holds up, will also provide a key to the first two. Perhaps the

39. San Antonio Independent School Dist. v. Rodriguez, 411 U.S. 1, 30 (1973) (Powell, J.); Lindsey v. Normet, 405 U.S. 56, 74 (1972) (White, J.); Dandridge v. Williams, 397 U.S. 471,487 (1970) (Stewart, J.). See also, e.g., Memorial Hospital v. Maricopa County, 415 U.S. 250, 288 (1974) (Rehnquist, J., dissenting); United States v. Kras 409 U.S. 434, $444-45$ (1973) (Blackmun, J.); Fuentes v. Shevin, 407 U.S. 67, 84 (1972) (Stewart, J.).

40. San Antonio Independent School Dist. v. Rodriguez, 411 U.S. 1, 29 (1973). 
answer to the third puzzle is that "essential" status is not conferred by any evaluative act of the Court or other extra-political agent, but is inferred-positivistically-by simple observation of the acts of the electorate itself. So viewed, "essentiality" would consist not in any unique content or intrinsic importance ascribed to the services that local governments typically provide, but rather in the simple factwhich the Court merely observes and records-that certain services are, with authorization from and possibly by mandate of the state, provided by local governments out of their general tax revenues. Since all these services can be, have been, and are now being privately provided, provision of them by local governments must mean that the electorate ${ }^{41}$ has concluded that such services ought to be provided collectively, in satisfaction of needs understood as (in some sense) community needs, irrespective of any individual's inability or unwillingness to pay for them out of private income. "Essentiality" would reside in just this fact of actual political acceptance of some view as (i) the service is a "public good" in the microeconomic sense, collective provision of which tends towards better satisfaction of private preferences than the private market could achieve; ${ }^{42}$ or (ii) the service is something that must be made freely available to everyone as a condition of some other social-justice conception that the electorate has accepted ${ }^{43}$ or (iii) it is in the community's interest that the rules of legitimate political struggle should be honored, and the service is one for which there is prevailing local support under those rules. ${ }^{44}$

Such a positivistic understanding of "essentiality," which would solve our third puzzle, would also provide a solution to our first onewhy $N L C$ 's protection from congressional interference should be restricted to governmental suppliers. We could say that what is precious about a public service such as education is not that it is education, but rather that it is education that has been politically decreed to be available without one's having to pay for it specially. The special reason for protecting governmental providers against clumsy and heedless congressional obstruction would be not that the governmental provider's product is somehow unique, but rather that the local government is the provider of last resort while the private supplier is just an optional alternative. If the private supplier were to be driven

41. That is, some combination of the state and local electorates and their legislative representatives.

42. See R. Musgrave, The Theory of Public Finance 44 (1959).

43. For example, it is a part of the "social minimum" or one of the "background conditions" in the conception proposed in J. RAwLs, A TheORY OF Justice 274-84 (1971).

44. Compare Posner, The De Funis Case and the Constitutionality of Preferential Treatment of Racial Minorities, 1974 SuP. CT. REv. 1, 26-31. 
out of business by the FLSA (Darby), the local government would remain able to provide the public good, or fulfill the conditions of social justice, or honor the rules of the political "game" (NLC).

We would be left, then, with the second of our three puzzles-how to defend the classification of a service as "essential" insofar as the local electorate would actually be unwilling to pay the full social costs (as authoritatively determined by Congress) of providing it. Of course, once granted that "essentiality" means just the fact (let us call this the "key fact") that a local government has been authorized to raise general taxes to pay for the service in question, there would be no contradiction in observing the additional fact that imposition of the minimum-wage requirement would cause some degree of taxpayer rebellion-some measurable reduction in the level of service that the taxpayers and voters are willing to finance. But it would remain unclear why the key fact-previous authorization of taxes to pay for the particular service- which is, after all, the vaguer and more remote expression of popular will, should be accorded such dominance over the more immediate and focused expression of that will implicit in taxpayer rebellion.

In order to see what sense it might make to treat the popular will as thus divided against itself, and as more authentically expressed by the key fact than by taxpayer rebellion, we have now to deal separately with the "public good," "social justice," and "rules-of-the-game" interpretations of the key fact, which we earlier lumped together. The "public good" and "rules-of-the-game" interpretations seem to offer no reason for severing judgments of "essentiality" from observation of the actual, day-to-day behavior of economic markets and political quasi-markets (as competently regulated by Congress). If the local voters find that the individual benefits they will severally receive from a service program are not worth a tax price that covers all of the program's social costs once minimum wage costs are included, ${ }^{45}$ then the technically "public" nature of some or all of those benefits offers no argument in favor of continued investment in the program. And if a congressional minimum-wage regulation has the effect of preventing a local interest group from prevailing in the local arena, the proper conclusion may be that winning the game of politics in this country requires successful play in Congress as well as at home.

Turn now to the social-justice interpretation of the key fact. On

45. Congress, it must be remembered, has officially determined that among the relevant social costs (from the national cconomic standpoint) are those resulting from payment of substandard wages. 
that interpretation, might there be an argument for protecting previously established levels of social services from congressional action that is likely to spur local voter majorities to reconsider whether their private benefits from the services are really worth the full social costs? One possibility is that, under the social-justice interpretation, the key fact might be construed as a political expression of society's commitment to the principle that individuals ought to be provided with some level of services without having to pay specially for them. That a current majority of local voters might prefer to deal with the extension of the minimum-wage law by foregoing services, or by obtaining more of their needs from private suppliers, would not answer an appeal to politically established principle by the minority who prefer neither to forego services nor to satisfy their needs privately, perhaps because they cannot afford to do so. And so, it might be argued, Congress must be prevented from tempting local electorates away from the social justice principles (embodied in extant social service levels) to which their prior political actions have committed them.

As we shall see, ${ }^{40}$ there are difficulties yet to be overcome. But it may be helpful to stop and consider the distance we have traversed. The $N L C$ decision, under the possible reconstruction I have suggested, would be composed of judgments and observations of various types.

Empirical observations would include the following: (a) In our constitutional system it is a historically accepted part of the governmental role to realize conditions of social justice by raising general taxes and using them to provide certain ("essential") services to everyone without special charge; and (b) the historically established popular understanding and expectation is that the responsibility of providing at least some of these services rests primarily and ultimately with state and local governments, not the central government.

Theoretical judgments would include the following: (c) If state and local governments must pay a minimum wage that exceeds what they have been accustomed to pay for equivalent labor in an unregulated market, the total budgetary costs of producing (and therefore the tax prices of demanding) any given level of service will be increased and the politically demanded level of services will be reduced; and (d) given the historically established understanding-reflected in the Tenth Amendment-of state and local responsibility for providing services, congressional attention to this economic consequence of imposing minimum-wage requirements on state and local governments may be so inadequate that the congressional action may not truly represent

46. Pp. 1184-91 infra. 
the choice of the electorate between allowing substandard wages and accepting reduced levels of local public services.

The crucial valuational judgment can, for the moment, be summarily offered as: (e) It is a bad thing to take the risk described in the theoretical judgments.

The legal judgment that follows from these might assume the following form: (f) The Tenth Amendment reserves for the states and the people all powers not delegated to the central government. When established constitutional practice assigns some well-defined governmental function to the states rather than to the central government, and that practice is harmonious with, if not expressly commanded by, the Constitution's restricted enumeration of the porrers of the central government, then that responsibility has been "reserved" to the states and not "delegated" to Congress. One such function is that of providing (authorizing provision by municipalities of) certain "free" public services in satisfaction of conditions of social justice. If Congress unreasonably or uncaringly impedes a state government's ability to carry out such a responsibility, Congress is exercising nondelegated powers and violating the principle of reservation to the states. Finally, congressional interference is prima facie unreasonable ${ }^{47}$ if conditions are such that Congress will (or may) not be held (sufficiently) accountable to the electorate for that action.

An alternative form of the legal judgment might run: $(\mathrm{g})$ It is a rule.implicit in the Constitution as a whole that Congress may not act so as critically to impair the sovereignty of the states; the states' "sovereignty" resides, in significant part, in their (municipalities') role of providing "free" public services so as to realize conditions of social justice. Congress commits a critical impairment of this aspect of state sovereignty when it acts ... (and so on).

Such a reconstruction would have wrought the $N L C$ decision into a general shape-I believe the only shape-that approaches both reasonable completeness and coherence and a tolerable consistency with the totality of the Court's opinion. Yet the same reconstruction, if accepted, would show the decision to contain (I expect most readers will easily agree) a very big surprise. The Supreme Court would, it seems, have intervened on behalf of the interest of citizens in receiving free social services. But even that characterization does not fully reveal the decision's surprising properties. As an aid to laying them bare, we call, in time-honored fashion, on a hypothetical case.

47. But the interference might be shown to be justified by a compelling need for congressional action. See the Court's treatment of Fry $v$. United States, 421 U.S. 542 (1975), in the NLC opinion, 426 U.S. at 852-53. 


\section{NLC in a New Key: Positivism and Beyond}

States typically authorize their local governments to impose general taxes $^{48}$ in order to finance free public services ${ }^{49}$ for their inhabitants. For the most part, the states leave it to local units to decide how heavily to tax and spend for these various service programs; they limit the tax base of local units to nonexempt property and transactions within local boundaries, producing wide inter-unit disparities in tax base per person (or per other plausible object of services); ${ }^{50}$ and they empower local units to regulate with a view to attracting tax base away from other units and repelling service-consuming households onto them. ${ }^{51} \mathrm{~A}$ common result is dramatic inequality in the services provided by local governments, inequality having no discernible relation to variations in need or desire for services. ${ }^{52}$

Consider a possible legal attack on this system by inhabitants of a unit having a much-below-average level of tax base relative to population (or other index of service needs), and spending at a much-belowaverage level on some or all of the authorized services. The plaintiffs can also, let us suppose, show that there is no higher-spending unit into which they can relocate and still be within reasonable reach of

48. By "general taxes" I mean those apportioning burdens across the taxpaying community by some measure (typically supposed to be one of ability to pay) other than that of the value of specific benefits received by individual taxpayers.

49. "Free" means that no one has to pay specially as a condition of receiving the service.

50. For cxample, according to the 1972 CENSUs of GovernMents, vol. 2, pt. 1, Taxable Property Values and Assessment-Sales Price Ratios, the gross assessed value of taxable property per capita was $\mathbf{S 2 . 3 9}$ in Bridgeport, Connecticut, while in neighboring Danbury the property tax base per capita was $\$ 4.15$, in Stamford it was $\$ 5.73$, and in Greenwich, \$22.11. Id. at 66 .

51. Recent decisions in some state courts have begun to indicate that such fiscally motivated municipal regulation may be impermissible under state constitutions or enabling legislation. E.g., Southern Burlington County NAACP v. Township of Mount Laurel, 67 N.J. 151, 336 A.2d 713, appeal dismissed and cert. denied, 423 U.S. 808 (1975); National Land \& Inv. Co. v. Easttown Township Bd. of Adjustment, 419 Pa. 504, 215 A.2d 597 (1967). It is quite unclear at this stage whether this is the true meaning of the decisions, or how far the tendency will progress or how wide it will spread. The federal judiciary has rather clearly indicated the riew that a state does not violate the Fourteenth Amendment by authorizing its local subdivisions to engage in fiscally motivated regulation. See James v. Valtierra, 402 U.S. 137 (1971); Construction Indus. Ass'n v. City of Petaluma, 522 F.2d 897 (9th Cir. 1975), cert. denied, 424 U.S. 934 (1976). See also Village of Arlington Heights v. Metropolitan Hous. Der. Corp., 97 S. Ct. 555 (1977); City of Eastlake v. Forest City Enterprises, Inc., 426 U.S. 668 (1976); Warth v. Seldin, 422 U.S. 490 (1975).

52. The most arresting data are those respecting educational services, submitted as cridence in litigation challenging state school-finance arrangements. See, e.g., Serrano v. Pricst, 5 Cal. 3d 581, 592-95, 487 P.2d 1241, 1245-48, 96 Cal. Rptr. 601, 605-08 (1971); Robinson v. Cahill, 118 N.J. Super. 223, 235-58, 287 A.2d 187, 193-202 (Law Div. 1972), supplemented, 119 N.J. Super. 40, 289 A.2d 569 (Law Div.), modified, 62 N.J. 473, 303 A.2d 273, cert. denied, 414 U.S. 976 (1973). 
their jobs or other strong personal ties; and that this situation is in part a result of various units' exclusionary exercise of state-granted regulatory powers. ${ }^{53}$

The plaintiffs' claim is that the state has a prima facie legal duty, under the due process and equal protection clauses of the Fourteenth Amendment, to make available to each of its inhabitants standard (though unspecified) levels of various social services (those typically provided by local governments), and, derivatively, to avoid unreasonable risks of substandard provision to any identifiable person or group. ${ }^{54}$ In support of this claim, the plaintiffs propose the following more specific legal rule: Once a state has chosen to delegate to local governments its function of providing free social services out of general tax revenues, then ( 1 ) that state must design its fiscal arrangements to ensure that no local unit need tax at a substantially higher rate than any other in order to raise any given amount of per capita revenue; ${ }^{z 5}$ and (2) the state may not allow any local unit to exercise regulatory or other governmental powers in order to exclude those potential residents who are expected to be fiscally burdensome. ${ }^{56}$

It takes no clairvoyance to see that the plaintiffs have no chance of prevailing in this lawsuit-not even of persuading a federal court that their substantive theory is correct in principle, much less of inducing

53. Warth v. Seldin, 422 U.S. $490(1975)$, indicates that it would be difficult and burdensome-though not impossible, see Village of Arlington Heights v. Metropolitan Hous. Dev. Corp., 97 S. Ct. 555, 562-63 (1977)-to prove the latter assertion with enough specificity to give the individual plaintiffs standing in a federal court.

54. While reminiscent of San Antonio Independent School Dist. v. Rodriguct, 411 U.S. 1 (1973), the hypothetical case advances a theory somewhat different from the one rejected there. Our hypothetical plaintiffs do not restrict their focus to education, or claim that it is an interest having a special constitutional status as compared with various other municipal services.

55. There is a rich variety of fiscal arrangements-"state aid" systems-that will satisfy the plaintiffs' proposed rule. See, e.g., J. Coons, W. Clune \& S. Sugarman, Privite Wealte AND Punlic Edecition 63-95 (1970). A more precise statement of the proposed rule would permit adjustments to the standard of per-capita services insofar as reasonably related to variations in service needs unrelated to population size-e.g., heavy commuter traffic; heavy incidence of disadvantaged or handicapped population requiring special services.

56. Regulations otherwise reasonably justifiable-say, for purposes of environmental protection-would not be invalidated by a de facto tendency to screen out the relatively poor; but such a de facto tendency might shift a substantial burden of justification to the governmental defendants to dispel suspicion of fiscal motivation. Compare the Supreme Court's treatment of jury-discrimination cases, e.g., Turner v. Fouche, 396 U.S. 346, 359-61 (1970).

The plaintiffs must tolerate de facto economic exclusion-as well as the possibility of low local spending on social services because of local political preferences unconnected with tax-base variations-because, as will be seen, their theory calls for judicial protection only against especially serious risk that the total functioning of the governmental system will fail to respond fairly to their interest in receiving an indefinable "standard" level of services. See pp. 1190-91 \& note 86 infra. 
the court to inject itself into the state's governmental affairs with some kind of affirmative relief. The plaintiffs' claim that the state has an affirmative legal duty respecting "standard" levels of "certain" services is enervatingly vague, lacks explicit support in the Constitution, and runs against the tide of precedent. ${ }^{3 \tau}$ Yet the plaintiffs have a joker to play (or is it a joke?). They are going to rely-heavily-on National League of Cities v. Usery.

Now constitutional lawyers could be forgiven for thinking that $N L G$ is the last decision our plaintiffs would want to rely on-for seeing it as the nail in their coffin, not the key to their salvation. The $N L C$ decision seems to say that states, as essential components in a carefully wrought federal structure, are legal persons having rights under the Constitution against the central government-not merely tautological rights that the latter shall keep within the bounds of the authority granted it by the Constitution, ${ }^{58}$ but more specific protections, analogous to those enjoyed by natural persons under the Bill of Rights, against certain kinds of intrusion by the central organs even when those organs are acting intra vires. States are said to have rights to their "integrity" including, most particularly, rights to "structure" their internal governmental affairs as seems to them best in the performance of their "traditional" governmental functions. These rights are compendiously called the states' "sovereignty" or their "sovereign immunity." And these rights, the defendants will argue, are operative even in Fourteenth Amendment settings. ${ }^{50}$

57. Sec cases cited in notes 6 \& 39 supra.

58. Even to recognize such a right on the state's part would not be quite tautological. See Massachusetts v. Mellon, 262 U.S. 447 (1923).

59. The defendants can find support in Rizzo v. Goode, 423 U.S. 362 (1976) (discussed at pp. 1193-94 infra), in decisions restraining federal courts from intruding upon state judicial proceedings in the course of protecting Fourteenth Amendment rights, e.g., Huffman v. Pursue, Ltd., 420 U.S. 592 (1975); Younger v. Harris, 401 U.S. 37 (1971), and in the cases cited in note 6 supra. NLC seems to provide the defendants strong additional support, as Judge Friendly recognizes. See Friendly, Federalism: $A$ Foreword, 86 YALE L.J. 1019, 1032 12.117 (1977). The defendants, however, will have to deal with Fitzpatrick r. Bitzer, 427 U.S. 445 (1976), which upheld application to state employees of a congressional fair-employment law based on $\$ 5$ of the Fourteenth Amendment (and allowed a back-pay recovery against the state treasury despite the Eleventh Amendment), stating that "[t]here can be no doubt that [prior decisions have] sanctioned intrusions by Congress, acting under the Civil War Amendments, into the judicial. executive, and legislative spheres of autonomy previously reserved to the States," id. at 455 , and noting that $\S 1$ of the Fourteenth Amendment, unlike the commerce clause, expressly purports to limit the authority (and thus expressly defines and curtails the sovereignty) of the state. Id. Thus the "sovereignty" claim is apparently less potent in Fourteenth Amendment than in commerce clause settings when it is congressional intrusion that the state seeks to withstand, see id. at $452-53 \&$ n.9. Whether the same is true respecting direct judicial vindication of Fourteenth Amendment rights is not quite clear. Bitzer itself rests on apparently shaky verbal logic. If it is true that $\S 1$ of the Fourteenth Amendment expressly curtails state sovereignty, it is equally true that the 
Our hypothetical plaintiffs will have to break down this reading of $N L C$ as an endorsement of such a broad states' rights conceptualism. For this task, it will not quite suffice to show-as Justice Brennan has done so impressively in his dissenting opinion-that the broad states' rights proposition is practically bereft of support in constitutional text or judicial precedent. ${ }^{60}$ After all, the Constitution sometimes means more than it says, and the Court in NLC might have been correcting its own oversight. So our hypothetical plaintiffs will of necessity be more inventive. They will have to show that the NLC opinion's broadly couched states' rights talk cannot be taken seriously as the Court's actual ground of decision in the case. And we have now seen how they can offer, in support of that view, the argument that a state's "sovereignty," as that expression is used in NLC, must be taken as a metaphor for its citizens' interests in the adequacy of the state's performance of its service functions; ${ }^{61}$ and that this "sovereignty," then, is legally operative only insofar as those interests themselves attract legal recognition, as by being heavily weighed in judicial appraisal of the reasonableness of central-government action that tends to impair a state government's ability to perform one or another of its functions. So if our hypothetical plaintiffs can show that the state has acted so as to infringe interests protected by the Fourteenth Amendment, the state cannot escape liability by showing that relief for the plaintiffs will necessitate some involuntary adjustment of its internal governance arrangements, unless it can show also that the necessary rearrangements would sacrifice some constitutionally cognizable interest of its citizens. ${ }^{62}$ There is, the plaintiffs argue, nothing in the $N L C$ decision that would automatically shield the state from liability.

body of the Constitution expressly makes congressional legislation under Article I, including the commerce clause, "the supreme Law of the Land; and the Judges in every State shall be bound thereby; any Thing in the Constitution or Laws of any State to the Contrary notwithstanding." U.S. CoNSr. art. VI, cl. 2. And consider the question expressly reserved in a recent Supreme Court decision, Hazelwood School Dist. v. United States, 45 U.S.L.W. 4882 (U.S. June 27, 1977), whether Congress is authorized by $\$ 5$ of the Fourteenth Amendment to prohibit employment practices of a local government that are racially discriminatory in their effects but not shown to be purposefully discriminatory. $I d$. at $4884 \mathrm{n} .12$. Given that Congress is empowered to provide against private-sector employment practices which unjustifiably-cren though unintentionallydiscriminate, see Griggs v. Duke Power Co., 401 U.S. 424 (1971), this ginger treatment of the local government question certainly suggests a possible residuum of state "sovereignty" even in Fourteenth Amendment scttings. But cf. Village of Arlington Heights v. Metropolitan Hous. Dev. Corp., 97 S. Ct. 555 (1977) (remanding for consideration whether defendants' refusal to rezone, not shown to have been racially motivated, violated Title VIII of Civil Rights Act of 1968, 42 U.S.C. $\$ \$ 3604,3617$ (1970 \& Supp. V 1975)).

60. But see note 5 supra.

61. See pp. 1167-73, 1179-80 supra.

62. As to whether there is any such interest that would be sacrificed by the remedies sought by our hypothetical plaintiffs, see note 86 infra. 
But liability for what? Where is the plaintiffs' cause of action? Although our prior discussion may not make the point explicitly, NLC contains the answer to that question, too. Not only is NLC not a shield for the defendants, it is the plaintiffs' Excalibur.

Suppose the defendants in the hypothetical case resist on the ground of "no state action." "For the state merely not to provide," the defendants might say, "cannot be twisted into a 'deprivation' or a 'denial' of anything by the state. If the state had totally refrained from providing social services out of general taxes, and from authorizing its local subdivisions to do so, there would plainly have been no 'state action' subject to attack under the Fourteenth Amendment. And since what the state is in fact doing is closer than that no-action benchmark to what the plaintiff is demanding, plaintiff cannot thereby have suffered a legal injury under the Fourteenth Amendment."63

But this article's earlier discussion showed it to be a necessary premise of $N L C$ that the role of providing social services either is one of the "powers" reserved to the states under the Tenth Amendment, or is implicitly ascribed to states by the Constitution as a whole. ${ }^{64}$ Either way, the social-service role is treated as a part of the legal conception of what it means to be a state within the public-affairs system established by the Constitution. Since it is that same Constitution that enjoins those same states from depriving persons of "life, liberty, or property" unreasonably ${ }^{65}$ and from denying persons "the equal protection of the laws," how (the hypothetical plaintiffs might well ask) can the states not be "acting" insofar as they fail to perform that same service-providing role that they, in order to prevail in NLC, must claim as a part of their character as "states." Whatever choice the state makes regarding its arrangements for carrying out that role-including the imaginable choice to leave everything to the private sector-is a choice it makes as a state and for which it is, therefore, accountable under Fourteenth Amendment standards of reasonableness, fairness, good faith (or whatever), and nondiscrimination.

This should suffice to get the plaintiffs past the "no state action" hurdle. They have found and turned to advantage a kind of organic positivism lurking behind the $N L C$ decision ${ }^{66}-\mathrm{a}$ judicial construction

63. See Michelman, The Supreme Court, 1968 Term-Foreword: On Protecting the Poor Through the Fourteenth Amendment, 83 Harv. L. REv. 7, 55 (1969).

64. Pp. 1179-80 supra.

65. That the due process clause still retains some such hard core of substantive content seems to be conceded even by such ultra-postivistic decisions as Meachum v. Fano, 427 U.S. 215 (1976); Bishop v. Wood, 426 U.S. 341 (1976); and Paul v. Davis, 424 U.S. 693 (1976).

66. Whether it is legal positivism is debatable. Compare H.L.A. Hart, The Concept OF LAW 97-114 (1961). 
of the legal conception of a state and its role in our constitutional system, drawn from an actual, historical, practical interpretation of the Constitution. ${ }^{\text {ir }}$ But to win their case the plaintiffs must finally get beyond positivism altogether.

For the defendants will say that, yes, the Constitution does reserve this service-providing role for the states and, derivatively, protects citizens against ill-conceived congressional interference with the states' performance of that role; but that, no, it does not follow from this that one has a legal right to receive services or that the state has a legal duty to furnish any. "The Constitution," the defendants will explain, "neither creates any such rights nor requires states to create them. It simply commits the problem of general, local public services to the states and asks Congress to keep out of the way. Plaintiffs may argue that the state created their right to a 'normal' service level by authorizing municipalities to provide services out of general tax revenues, so that having thus created that right the state must now act in a manner consistent with its nondiscriminatory enjoyment. But that argument would be self-defeating. Plaintiffs have no basis for carving out one piece of our whole local-government scheme to be viewed in isolation from the rest. The authorization for local-government provision of services out of general taxes occurs within the same total regime that leaves municipalities to raise revenues within their own borders, and that allows fiscally motivated regulatory exclusion. It is this total system," the defendants will argue, "that is the actual political expression of the state's 'social welfare function' and that thus defines plaintiffs' rights in the area of social services. The plaintiffs have to take, as it were, the bitter with the sweet. ${ }^{6 s}$

"Finally," the states will conclude, "this case is poles apart from NLC: There the Court struck down just the sort of congressional interference with the states' search for solutions to the dilemmas inherent in their social-welfare responsibilities that the plaintiffs are demanding here. Surely the electorates of the several states are far better situated than any organ of the central government-and espe-

67. Cf. Meachum v. Fano, 427 U.S. 215, 216 (1976) (reference to state's "law or practice" as source of legal rights); Perry v. Sindermann, 408 U.S. 593, 602-03 (1972) (finding substantive rights implicit in state agency's long-continued practicc).

68. See Arnett v. Kennedy, 416 U.S. 134, 154 (1974) (Rehnquist, J.) (plurality opinion). The majority's insistence in Arnett on stopping short of Justice Rehnquist's bitter-end positivism, which remains at least nominally the Court's position, see Bishop v. Wood, 426 U.S. 341, 344-46 (1976), seems consistent with the hypothetical plaintiffs' view of what $N L C$ really means, see pp. $1187-90$ infra. Full exploration of the relationship between the Supreme Court's use of the "entitlement" notion in procedural due process settings and its decision in $N L C$ would, I think, be a worthwhile and revealing enterprise but I do not undertake it here. 
cially its judicial organ-to make and be held accountable for the accommodations among various social-welfare goals implicit in any local-government system."

Once again, the plaintiffs have an answer in the NLC case. They can show that there the legal conclusion was logically unattainable without a moral intuition by the Court, not relying on positive law, of something very like a right to receive specific social services. True, it looks as though the necessary judgments about what services ought to be provided by local governments are simply readings by the Court of authorizations actually voted by the state and local electorates, so that not the Court but these electorates are the real authors of any implicit moral judgments; and it looks as though the Court intervenes only to protect these state and local political judgments from the distortive effects of a dubiously responsible congressional intervention. But several considerations converge to show that these appearances are false.

1. The Court's doctrine in $N L C$ is, as a matter of fact, not expressive of respect for the actual judgments or decisions of state and local electorates. A politically sanctioned governmental activity is, by that doctrine, accorded no greater protection than any private activity enjoys, unless it also falls into a judicially defined special category of activities variously styled "integral"; ${ }^{69}$ or "typical" or "traditional"; or "essential," "important," or "required."71 "Integral," we have already noted, simply defies comprehension unless it means something like either "traditional" or "important."72 "Traditional" is intelligible enough, but lacking in apparent relevance to the issue before the Court in $N L C$ unless it, in turn, is meant as a proxy for importance. ${ }^{73}$

69. See p. 1172 \& note 26 supra.

70. See p. $1172 \&$ notes $27 \& 28$ supra.

71. See p. 1172 \& note 28 supra.

72. See note 28 supra.

73. Railroad opcration, we carlier noted, although in ordinary perception a recog. nizably different governmental activity from sereral scemingly traditional ones like water utilities and intraurban transit lines, cannot be distinguished from the latter in terms of any gencral principles for determining what activities arc suitable for governments. See note 28 supra. Why, then, should the superficial novelty of governmental railroading exclude that activity from the protection of the $N L C$ doctrine, if not because that novelty suggests some lack of enduring, urgent need for that particular sort of governmental involvement? If the Court in $N L C$ were elaborating and implementing some express mandate of the Framers to protect "state governmental activitics" (or some like category) from congressional interference, it might be arguable that the Framers' intent should be gauged by reference to traditional, popular understanding of what state governments do. But the Court's NLC doctrine is not an elaboration of specific constitutional phraseology but an inference from the total constitutional design-from our "federal system of government," 426 U.S. at 844,852 . That being so, the relevant question about state railroading would seem to be whether it is on principle distinguishable from other, protected activities; not whether it would popularly be perceived as norel. 
So the doctrine as enunciated makes the judicially determined importance of a state or local governmental activity a determinant of its protected status vis-à-vis commerce clause regulation. ${ }^{74}$

2. A state or local electorate's authorization of a governmental service activity might reflect the electorate's judgment that social justice demands provision of the service, but it also might reflect a quite different sort of judgment that the service is a "public good" in the technical economic sense, or just a commitment to abide by the rules of the "game" of politics. ${ }^{75}$ Only on the social-justice interpretation of the electorate's authorizing acts is there much of an argument that congressional imposition of a minimum-wage constraint on the resultant activities amounts to an untoward "interference" that could justify judicial intervention. ${ }^{76}$ But since there is no way of telling, a priori, whether the local electorate has acted on social-justice or other grounds, the Court's decision to intervene must reflect its own perception that social-justice considerations are involved.

3. Even if the state and local electorates could somehow be seen as certifying to the Court that their authorizations were prompted by considerations of social justice, as distinguished from concerns about market failure or abiding by rules of the political "game," it is still unclear why there should be any valid objection to congressional intrusion. Certainly there are some widely accepted conceptions of social justice under which determination of the obligatory levels of social services is not wholly independent of the social costs of providing them. Under such conceptions, it is unclear why congressional insistence that state and local communities consider (avoid) ${ }^{7 \tau}$ the social costs of substandard wages should be regarded as distortive rather than corrective. If the vice of substandard wages (as Congress sees it) is pitted against the injustice of substandard services (as the state and local communities see $i t){ }^{78}$ why should not the more comprehensive and broadly representative judgment prevail?

74. Even if "tradition" or "typicality" is the only criterion used for assigning activities to the protected and unprotected categorics, the determination is judicial in that it rests on a judicial application of that criterion, and not on a reading of the political will of the electorate of the complaining state or local government.

75. See p. 1177 supra.

76. See pp. 1178-79 supra.

77. From Congress's standpoint as guardian of the national economic welfare, the problem is to "internalize" to state decisionmaking the social costs (as Congress sees them) associated with employment at substandard wages. Adoption of a scheme of regulatory prohibition (the FLSA) evidently rcpresents a congressional determination that such is the best (if not the only) way to accomplish the desired internalization. See generally G. Calabresi, The Costs of Acciblsts 68-130 (1970) (discussion of "specific" vis-at-ris "general" deterrence).

78. For discussion of a difficulty in this characterization, sec p. 1176 supra. 
4. The answer I suggested at the outset of my effort to make sense of the NLC decision ${ }^{70}$-that the Court's intervention reflects skepticism about congressional accountability for the adverse impacts on state and local social-service programs of the FLSA amendments-is inadequate and unpersuasive standing by itself. At issue in $N L C$ were amendments to the FLSA specifically extending the minimum wage in steps, first to employees of state schools and hospitals, ${ }^{80}$ then to the bulk of state and local government employees. ${ }^{\mathrm{s} 1}$ The sharpness of congressional focus on the issues at stake, the visibility of congressional deliberation, the clarity of congressional statement, and the vigor of the "cities" lobby should not have been in great doubt. s" Of course, one might always worry about whether Congress has adequately understood and appraised the consequences of its actions; ${ }^{\mathbf{8 3}}$ but there is no possible reason for special worry when the congressional action consists of regulating state and local governmental payrolls-unless it be some special weight that the Court attached to the interests threatened by cutbacks in local social service levels. Judicial doubts about congressional accountability can explain the $N L C$ result only as they are energized by special judicial regard for the interests to which Congress was putatively insensitive.

"So," reason the plaintiffs in our hypothetical case, "the role that the Court must have ascribed to the states in $N L C$ was not simply that of solving, somehow, the social-welfare problem-of finding and then realizing a politically preferred social-welfare function whatever it might be. The role must have been that of satisfying social justice concerns that the Court ranked ahead of whatever interests were served by allowing Congress to proceed with the FLSA amendments. The attribution of this role could not have depended on any narrowly positivistic, logical inference from the actual behavior of any particular local or state electorate or legislature, or of all of them and Congress

79. See pp. 1173-74 supra.

80. Fair Labor Standards Amendments of 1966, Pub. L. No. 89-601, \$ 102(a)(1), 80 Stat. 831 .

81. Fair Labor Standards Amendments of 197-1, Pub. L. No. 93-259, $\$ 6(a)(1)$, 88 Stat. 58.

82. Cf. Tribe, Intergovermmental Immunities in Liligalion, Taxalion, and Regulation: Separation of Powers Issues in Controversies About Federalism, 89 Hakv. L. Rev. 682, 697 (1976) (footnote omitted):

[T]he clearer the history of state attempts to immunize institutions and activities from answerability in a federal forum, and the more onerous the restriction on state options represented by a coerced waiver of immunity, the more courts should insist that Congress act in a fashion demonstrating full appreciation of the consequences for federalism.

83. As the Court plainly worricd in NLC. See note 35 supra. 
in combination. It could only have been a morally creative judicial act implying recognition of inchoate personal rights. Its sources and justifications may be obscure," the plaintiffs conclude, "but this much is clear: if $N L C$ is to be understood thoroughly and taken seriously, then the defendant state's denials in this [hypothetical] case that a right to services can be deduced from its electorate's actual political behavior are, while perfectly sound, beside the point.

"Of course we appreciate how vague our claim of inchoate rights has been, and must remain. But that was no less true of the inchoate rights that prevailed in $N L C$, and it poses no more of a problem here than it did there. $N L C$, when we get to the bottom of it, turns out to be a case in which congressional action that seemed to carry a substantial risk that some persons would be denied certain services is for that reason subjected to special judicial scrutiny-or, in other words, it is a case in which receipt of those services was treated as a right. ${ }^{8 t}$ Now, however one may appraise the seriousness in $N L C$ of the risk that social services would be unfairly or irresponsibly denied, there can be no doubt about the analogous risk in this case. If the state leaves to the mercies of local electorates satisfaction of its general obligation to provide social services out of taxes, under political arrangements that allow and invite people to vote according to their parochial interests, it creates an obvious mismatch between political process and substantive aim-an obvious accountability defect-an obvious risk that the general social obligation will not be fairly or adequately weighed in the decisions that result."

And so the analogy is complete. In the hypothetical case, just as in $N L C$, the plaintiffs are unable to state with precision the level of services to which they are by right entitled. All they can say is that there is some such level, that they have to rely on political processes to define it, and that-just because they do have to entrust the definition of their rights to politics-they are entitled to have the question put to political institutions that are as likely as any available to take it seriously and respond to it conscientiously. If Congress in enacting wage regulations is not such an institution with respect to the social services the Court was thinking of in $N L C$, a fortiori self-interested local voter majorities in a mercantilistic local-government system are not either. The underlying substantive rights claimed by the plaintiffs may remain, so to speak, inchoate and nonjusticiable; but still they exert legal force, become legally operative, through the justiciable institu-

84. The notion of "rights" here is closely akin to that proposed by Ronald Dworkin. See, e.g., Dworkin, Hard Cases, 88 Hakv. L. Rrv. 1057, 1068-70 (1975). 
tional rights that they inspire. The general idea-not invented for this occasion-is that judicial incapacity, without legislative assistance, to give concrete content or effect to certain inchoate rights does not imply judicial incapacity to seize upon political actions that are visibly responsive to those inchoate rights, and thereafter to regulate institutional frameworks with a view to protecting the claims that grow out of political actions. ${ }^{85}$ National League of Cities $v$. Usery is, I believe, an unwitting case in point. ${ }^{86}$

85. See Grcy, Procedural Faimess and Substantive Rights, in DuE Process 182 (NOMOS XVIII; J. Pennock \& J. Chapman eds. 1977); Michelman, Formal and Associalional Aims in Proccdural Due Process, in id. at 126; Michclman, In Pursuit of Constitulional Welfare Rights: One View of Raz's' Theory of Justice, 121 U. P.1. L. REv. 962, 1013-15 (1973); Tribe, Structural Due Process, 10 H.iRv. C.R.-C.L. L. Rev. 269 (1975).

86. What limits are there, then, to the decision's reach? Would it, for example, stand in the way of congressional action to reduce extant levels of federal financial support for social-scrvice programs of state and local governments? What of the countless instances of congressional or executive action (e.g., respecting petroleum imports or fullemployment policy) that through their direct or indirect effects on factor prices may tend to reduce the levels of social-service offerings that state and local electorates will support?

The question about reduction of direct financial support for service programs is the casier to deal with. The argument supporting special judicial attention to procedural or institutional frameworks for decisions respecting the size and shape of certain governmental service programs grows out of the perceived nonjusticiability (reflecting both indeterminancy of substantive standards and lack of direct remedial competence) of the claims of right to which those programs are (in this argument) responsive. A court incapable of saying just how much education justice requires, or of effectively ordering that any given volume of resources be appropriated or service level be met, may nevertheless be able to say with sufficient confidence and trenchancy that there is a defect in ccrtain procedures through which the polity effectively makes those decisions, a defect that could be corrected at acceptable cost. Such defects arc, however, most clearly absent where a legislature directly decides what volume of resources to appropriate to a service program. So it docs not follow from my suggested reading of $N L C$ that a suit would lie to prevent a cutback in federal subventions.

On the other hand, institutional (accountability) defects are likely to loom especially large in cascs of congressional action-in fields such as import controls, monetary and employment policy-where the effects on service programs are somewhat remote, consequential, and obscure, and therefore probably not salient factors either in legislative deliberations or in popular appraisal of legislative actions. But to the extent that is so, it is likely also that isolating state and local governments from the price impacts of such actions will be impossible or extremely impracticable. Thus protecting their socialservice programs from such impacts would be possible only by forgoing the congressional program of economic (or whatever) regulation entirely. And since the doctrine I am reading into NLC would not protect social-service programs at all costs-would not prevent Congress from hindering them in pursuit of a compelling (or substantial, or whatever) governmental interest-it might well follow that regulatory programs having only consequential and nonisolable impacts on state and Jocal governmental operations would remain unaffected by the doctrine. Thus it is a significant feature of the minimum wage that its enforcement with respect to state and local governmental payrolls can be forgone with no impairment of the residuc of Congress's regulatory program.

The conclusion I have offered in the text is not meant to be by itself dispositive of the hypothetical case. Other problems requiring exploration would include the court's fact-finding and remedial competence, see generally Chayes, The Role of the Judge in Public Law Litigation, 89 Harv. L. Rev. 1281 (1976), and the question of justification for the established local-government system in the form of legally weighty interests 


\section{IV. $N L C$ as Precedent}

Justice Brennan thinks that the sovereignty notion in $N L C$ is "an abstraction without substance," serving in the first instance as a cover for mere judicial "displeasure with a congressional judgment" which, the Justice also thinks, is really the determining factor in the decision. ${ }^{87}$ One can easily sympathize with this view, ${ }^{\$ 8}$ as with the extended form of it that sees the state sovereignty constraint as an "ominous portent" for our constitutional jurisprudence ${ }^{s 9}$-presumably because the sovereignty notion, being a mere "abstraction," is lacking in empirical referents, is just a figure of speech, and therefore will remain available to disguise future (perhaps unwitting) acts of judicial arbitrariness or usurpation.

Yet I doubt whether the Court's sovereignty category is as empty, abstract, or insubstantial as Justice Brennan believes. I think it does have a readily comprehensible and empirically applicable contentroughly expressible as a state's interest in determining its own internal governmental arrangements and affairs-that will make it devastatingly applicable in other cases (our hypothetical case included). That, indeed, is what makes the situation ominous. What makes it outrageous, I suggest, is that the "state sovereignty" invoked and canonized in the NLC opinion is a falsification of the considerations (that is, of social justice and inchoate welfare rights) that alone might provide an ultimately satisfying explanation for the result in that case-a falsification in the sense not only of obscuring those considerations but also of twisting them into a doctrinal form in which they will influence decision in an important class of future cases (of which our hypothetical case is a member) in a direction exactly the reverse of their true meaning. The $N L C$ decision thus preys upon the social-justice

served by the system, see p. 1184, supra. The most interesting possible justifying interest is community self-determination viewed as an intrinsically valued process. A number of recent decisions strongly suggest judicial appreciation, still somewhat veiled, of such an interest. See City of Eastlake v. Forest City Enterprises, Inc., 426 U.S. 668 (1976); Village of Belle Terre v. Boraas, 416 U.S. 1 (1974); James v. Valticra, 402 U.S. 137 (1971); sec also Young s. American Mini Theatres, Inc., 427 U.S. 50 (1976); Milliken v. Bradley, 418 U.S. 717 (1974); San Antonio Indepcndent School Dist. v. Rodriguez, 4ll U.S. 1 (1973). Further investigation of this sensitivity to community self-determination, its role in the cited decisions, its theoretical significance, and its relationship to the issues in NLC, must await another article.

87. 426 U.S. at 860,872 .

88. It is not reassuring to find in the Court's opinion a rehearsal, having no discernible relevance to the line of legal argument on which the Court's conclusion depends, of a standard litany of reasons why (some pcople think) the minimum wage is unwise policy. See $i d$. at 8.18 .

89. II. at 880 . 
impulse, depending on that impulse for its plausibility but emasculating it in the process. For the fact is-and here we find an additional element of truth in Justice Brennan's charge of empty abstractionthat the verbal notion of state "sovereignty" cannot süstain the highly figurative and specialized meaning it momentarily assumes at a crucial juncture in the $N L C$ decision. ${ }^{90}$ Even as the notion of "sovereignty" at that moment embraces a veiled thesis respecting states' service rolesimplying duties and obligations-in our constitutional system, the same notion continues to carry its ordinary, and antithetical, connotation of states' rights and immunities. It is the former, momentary, meaning that gives the NLC decision its self-contained plausibility. But it is the latter, ordinary meaning that obscures the decision's revolutionary potential and that, not coincidentally, can be expected to survive as legal doctrine.

Nothing better illustrates this tendency than the Supreme Court's contemporaneous decision in Rizzo v. Goode. ${ }^{91}$ The Court there raised three obstacles to the plaintiffs' demand for relief against police department supervisors for their failure to respond-e.g., by instituting a disciplinary procedure-to an alleged pattern of racially abusive behavior by police officers. First, the Court doubted whether the causal relationship between the defendants' supervisory inaction and possible future injuries to the plaintiffs was sufficiently certain to precipitate a justiciable "case or controversy." ${ }^{2}$ Second, the Court concluded that the defendant supervisors, themselves not charged with any discriminatory or abusive acts, had violated no civil rights by their mere inaction. ${ }^{93}$ Third, the Court thought that "principles of equity, comity, and federalism" argued against federal court intrusion upon the managerial affairs of a local government. ${ }^{94}$

Insofar as the first two responses are at least somewhat surprising in view of recent precedent, ${ }^{95}$ the third ("federalism") point is crucial to the credibility of the decision. And of course that federalism point immediately strikes one as a natural corollary of the state-sovereignty principle articulated in $N L C$. Certainly the two decisions seem quite harmonious and mutually supportive, each tending to vindicate the

90. See pp. 1187-90 supra.

91. 423 U.S. $362(1976)$.

92. Id. at 371 .

93. 42 U.S.C. $\$ 1983(1970)$, on which the plaintiffs relied, makes one civilly liable for acts committed "under color of" state law which deprive another of any "rights .. secured by the Constitution and laws" of the United States.

94. 423 U.S. at 379.

95. See, e.g., Chayes, supra note 86, at 1305; The Supreme Court, 1975 Term, 90 H.Akv. L. REv. 56, 238 (1976). 
other. ${ }^{96}$ The deeper truth, I have argued, is otherwise. Analyzed to the bottom, the $N L C$ decision proves insupportable except as it depends on a perception that "states as states" under the Constitution are imbued with affirmative duties towards their citizens. ${ }^{97}$ On such a view, it is immediately obvious that those intrinsic duties include protection against assault, battery, false arrest, false imprisonment, defamation and other hard-core torts. ${ }^{98} \mathrm{Add} \S \mathrm{I}$ of the Fourteenth Amendment, and the intrinsic state duties also include protection against racially animated imposition by government agents and protection against racially discriminatory law enforcement. So if "federalism" in Rizzo is to be understood in harmony with "sovereignty" in $N L C$, its invocation should refute rather than support the conclusion that the Rizzo plaintiffs failed to state a cause of action against the quiescent supervisors. ${ }^{99}$ And the more one sees the Rizzo plaintiffs as claiming that they are specifically entitled to the state's protection (as distinguished from relief for unprevented, active harms), the more incredible becomes the suggestion that they have no concrete "controversy" with the defendants.

It may strike many readers as perverse to fancy that the Rizzo and $N L C$ decisions are deeply at odds with one another, and some may find this essay's pretense at plumbing the depths of $N L C$ just a gossamer of speculation that leads away from rather than into the decision as it really is. Yet without the conception of a state's duty and the socialjustice impulse that I say underlie the decision, what escape is there from the perfect impasse towards which a positivistic dual-sovereignty conception seems bound to lead? Take away that conception and that impulse, and the category of state sovereignty is precisely matched by an opposed category of national sovereignty; the rightful dominance of the states within their realm is precisely matched by that of Congress within the national realm; the location of responsibility for social services within the states' realm is precisely matched by the location of responsibility for national economic welfare within the congres-

96. Because Rizzo rejected a claim under the Fourteenth Amendment, use of a statesovereignty notion there may go beyond use of a like notion in NLC. See note 59 stupra.

97. Pp. 1173-91 supra.

98. See The Civil Rights Cases, 109 U.S. 3 (1883).

99. Possibly the supervisors could claim that the state, and not they as individuals, owes the duty, and that the plaintiffs have, therefore, failed to join a necessary party defendant. (The defendants are proper parties, too, because any cquitable relief will be directed to them.) The plaintiffs would not much object to a disposition thus requiring them to amend their complaint-or to conform with whatever revision of the doctrine of Ex parte Young, 209 U.S. 123 (1908), might be entailed. Given both Young and Fitzpatrick v. Bitzer, 427 U.S. 445 (1976), it would be surprising if the plaintiffs were defeated by a strict sovereign immunity defense. 
sional realm; the institutional error of allowing a putatively insensitive Congress to alter the economic equations that determine local-government service levels is precisely matched by that of allowing narrowly self-interested local voter majorities to disregard national social costs in constructing those equations; and if vox populi is the only judicially cognizable source of a social-welfare function, there can be no judicially cognizable answer to the question of which strain is to prevail when the people speak, simultaneously but discordantly, through their state governments and through Congress. 